\title{
METHODOLOGICAL ASPECT OF CONTROLLING CORPORATE INCOME TAX
}

\author{
Ivan M. Milojević, Milan B. Mihajlović and Vladan D. Vladisavljević \\ University of Defence in Belgrade, Military Academy
}

\begin{abstract}
$\Delta$ udit is an instrument of government and company management, which helps in timely detection of weak points of internal control systems, prevention of abuse and illegal appropriation. At the same time, it proposes measures and activities to eliminate detected weaknesses within an organization and helps in the functioning of internal control systems.

Audit is very important for storing accounting and financial records of an organization, as well as its management. Therefore, everybody is interested in auditing, from external auditors to management, board of directors, from shareholders of large public companies to the state.
\end{abstract}

Key Words: audit, company, financial report, system

\section{Introduction}

$\mathrm{T}$ he usual definition of an audit is that it is a process, established and systematically conducted by the state, with the goal to establish belief in truthfulness of the presented financial reports, in order to achieve the most important goals in the following documents: reliability of financial reporting, compliance with the existing laws and regulations (primarily tax), protection of assets from unauthorized appropriation, use and alienation, as well as proper relation to the commitments that a company has to the society and the state. This definition reflects some basic concepts: 1) Audit is a "process", which means it is not an event or a circumstance, but a series of activities, which audits business operations. These activities are significant and they are an integral part of the way that a company is managed. 2) Audit is performed by state services, as well as company management in order to introduce adequate control mechanisms. 3) It can be expected from an audit to provide reasonable and absolute conviction to company owners in the quality of management work regarding its obligations to the state. The probability of completion of those goals is affected by limitations inherent to all control systems. 4) Audit is applied in order to achieve goals in one or more than a few categories, which overlap.

There are four basic categories of goals in auditing [1]:

- Business - related to legal use of company resources,

- Tax reporting - related to the credibility of a tax balance, and in accordance with that, published financial reports,

- Compatibility - related to the compatibility of company operations with the existing law and regulations (primarily tax), and

- Protection of budget funds. 
Goals related to auditing and compatibility with laws and regulations are based on standards and depend on the way in which control has been performed within an organization. Operational goals such as profit from investment and market participation are not always under direct control of owners, so audit as an external control type contributes to owner's safety, primarily by influencing the quality of management business operations. The analysis performed by the audit firm, KPMG in the USA, has shown that $75 \%$ of 500 companies, which were included in the research, pointed out that their basic problem was embezzlement, and that $77 \%$ stated at least one such case in the last year. It was estimated that such losses amounted to 244 million US dollars a year. The analysis has also showed that the most common way in which it was discovered was either an audit or internal control.

Audit is primarily interested in controls related to the reliability of financial reporting. Financial reporting is a process in which actions can be vaguely expressed and it represents a completely different picture of a person's business. If controls are adequate they will ensure that, if for example all invoices, cash receipts, write-offs, refunds or corrections are accurate, the final balance on a specific account will probably be accurate.

\section{Basic principles of auditing}

When tax control is in question, it is in fact thought of the basic rules of conduct, which are the consequence of accumulated practical experience and achievements of theory and practice. Having that in mind, principles are the foundation of practice, which have theoretical basis confirmed by practice. Principles understood in this way are not something that is given forever and which is not susceptible to change, on the contrary, by developing theory and practice there is a change - perfection of tax control principles.

With respect to international experiences, views of national and international authors, based on consideration of the essence of auditing, its role and meaning in contemporary market economies, the following principles can be singled out [2]:

- Lawfulness,

- Professional ethic,

- Expertise and competence,

- Responsibility,

- Documentation (obtaining evidence), and

- Correct reporting.

Lawfulness is one of the oldest principles, which demands that the tax authority that performs audits must uphold the existing laws and other regulations in its work.

Professional ethic implies that tax control must uphold certain rules of conduct in its work and behavior in order to protect itself and improve its reputation. Moreover, inappropriate conduct of individual tax controllers, which can undermine the integrity of the profession, must be prevented, and the state should be the authority, which should take care of it.

Expertise and competence demand that tax controllers, other than certain ethical and moral norms should have an adequate level of education and knowledge, which enables them to perform quality control. 
With the responsibility principle the state commits to determine and quantify concrete responsibility for omissions in work through auditing. Other than that, it is important to note that controllers are directly and indirectly responsible for their work, and the state essentially takes full responsibility for their work.

Documentation principle is in close connection (as well as other principles) with proper bookkeeping principles. In this context it is considered that every business change must be accompanied by proper relevant documentation. Other than that, in contemporary conditions the documentation principle implies that the opinion on an audit must be based on evidence, which is documented.

Correct reporting principle obligates tax auditors to report truthfully on all determined irregularities found during the audit process in an organization. Untruthful reporting entails certain consequences regarding responsibility.

Methods that an audit uses when performing its mission are in direct relation to the principles and they are susceptible to continuous improvement.

\section{Proposition of an audit model}

It has already been noted that operations of contemporary business as a system are the object of attention of many subjects and that the data on its operations, state and results is available in accounting and presented to the public through financial reports. Let us consider the amount of changes that a large system has in its operations and how hard it is for a disclosed report to show correct data on financial, property and any other position of that system.

Adequate audit should give feedback on accounting reports created in the frame of most common goals of financial reporting, based on accounting assumptions and principles and under significant influence of a company's adopted accounting policy.[3]

In the least, contemporary auditors are not certain whether financial reports have been compiled in accordance with accounting and tax regulations, principles and standards, unless external audit that a company is obliged to fulfill, performs its mission.

The audit work is entrusted to the audit professionals, whose task is to add trust to disclosed financial reports. Tax auditors perform control over company's financial reports with the goal of timely prevention of tax evasion of corporate income tax, which companies are obligated to pay in accordance with which they make a tax balance as an instrument that serves for verification of adequate business operations. Tax balance is an unbiased instrument that is a mirror of taxpayers operations despite other financial reports that differ from company to company either formally or essentially. In order to conduct tax auditing of financial reports successfully like any other activity it must additionally perfect the methods and rules that it will use in the future. Methods always contain rules, which should be abided to, and rules arise from theory of a certain scientific discipline - in this case public finance.

According to it, it is wrong to separate and observe theory and methods independently. The unity of theory and methods is reflected in the fact that the system of attitudes of a theory contains the rules (principles) of the method, as well, which should be conducted. Other than that, audit methods are established by object, subject and principles. [4]

When auditing methods of financial reports are in question, it is necessary to consider them in the context of interdependence, on the one hand with theoretical attitudes on control and on the other hand with the object and subject of control. 
It is common to think that audits use some common methods, used in almost all areas of business control, out of which most common are inductive, deductive and experience methods. However, the state primarily uses its specific methods when performing audits, also known as specific control method. Among those specific control methods there are intensity of examination method, direction of examination method, area and continuity of examination method, as well as way of testing method.

Other than that, it has lately been pointed out that control should use analytical methods in its examination, which are based on parsing and comparing. A similar approach can be found in American literature, where it is emphasized that audits, among other things, include certain analytical procedures such as, for example, comparison (primarily through comparative financial reports) and use of indicators (primarily meaning indicators of financial analysis and analysis of financial reports). Other than that, when considering the future development of Serbian tax practice, the significance of using analytical procedures in control is pointed out.

On the basis of knowledge of basic tasks of auditing, as well as methods and procedures that it uses, its orientation to successful operation of the budget system, primarily proper relationship of a company and the state through credible financial reports, it can be concluded with a certain dose of safety what its place and significance at a global and state level is.

The adequate positioning of place and role of auditing is uncommonly important for all users of financial (and of course auditing) reports because if the users can understand them better, they will improve their position in making better decisions, giving them a bigger advantage to other users of financial reports. Such interpretation primarily starts from auditors. It should also be noted that a minimum of knowledge in accounting is required, or as it is often known, an inadequate title - accounting literacy. [3]

Insisting of the state on consistent respect of determined principles and standards when making and disclosing financial reports through auditing, implies that audits in the future should undergo with the application of certain methodology. Everything is directed at achieving a basic goal, which in essence comes down to the fact that information disclosed in financial reports at a global and state level should be precise, credible, mutually comparable with the goal of stable and safe budgeting regarding corporate income tax. Therefore, contemporary tax control makes efforts in reducing tax evasion.

This way of auditing is based on feedback on company management, primarily through owners. If there is larger expenditure regarding corporate income tax, owners can look at it ambiguously, some will look at it as successful performance of a company, while others will look at it as a failure of the management due to the owners' excessive desire for profit. This is one of the dominant reasons why the accounting profession in market economies is considered as one of the pillars of maintaining the owner's profit.

\section{Projection of limitations of an audit}

When explaining restrictions we will try, as much as possible, to explain and quantify their influence on the results of control as a whole. Limitations, which will be pointed out are related to control of financial reports by audits, and they will be grouped in the following way [5]:

- By the method of selection and use of samples;

- When control is performed in the conditions of a modern computerized accounting system;

- Regarding control and other relevant risks; and

- Relevance of the acquired evidence. 
In essence, auditing is based on samples because examining all changes - transactions would require too much time and it would be very expensive. It is notable to say that complete examination is unnecessary in most cases because the goal of audits is to acquire enough credible evidence to enable an appropriate conclusion regarding the correctness of reports on funds that a company provides to the state. However, there are very rare occasions in which auditors will decide to examine the entire population.

Since control is based on samples, in regard to that there is a sampling risk. It is the risk that exists due to the possibility that conclusions based on results of examining a sample would be different from a conclusion that an auditor would make if they performed control procedures on the entire population, making it a significant limitation.

When creating their control methodology, auditors should determine appropriate ways of selecting a sample in order to acquire evidence for achieving the goals of this type of control. However, it is very difficult to put this request into practice. Sampling in auditing systems can be statistical and non-statistical. Statistical sampling is based on laws of probability while in non-statistical sampling control is based on subjective judgement in determining the size of a sample and evaluation of results. Due to this, in non-statistical sampling there is always a latent possibility for auditors not to select a representative sample. However, both can and do give effective results if they are designed properly, and the basic difference is in the fact that statistical sampling enables measuring sampling risks, i.e. enables better view of samples representability in relation to the population. [6]

If auditors decide on applying statistical sampling (which is significantly more represented in practice), it has methods of non-systematic and systematic sampling, block pattern and random sample at its disposal. All of these actions related to the choice of sample are called methods of planning samples. We are of an opinion that all mentioned methods, despite certain limitations, can be applied in practice successfully, which again depends on assessment and decision of auditors. Auditors can, for example, decide to apply random sample method for control of accuracy of entries regarding debt based on declared tax by using [7]:

- Random number tables;

- Systematic selections;

- Random number generators.

We would like to point out one more time, no matter which sample is selected, it must be representative (it must reflect the entire population with its relevant features), i.e. it must provide a certain degree of reliability of obtained results with optimal conditions of speed and efficiency. Thus, when a sampling population consists of all items and changes that are related to it, a sample is selected out of it and results can relate only to that population (in our case to financial reports as a whole).

Auditors will have full freedom in applying sampling, so, for example, they can decide to define a population that includes certain transactions of an earlier date, and then consider whether additional tests are needed for the remaining period, which will depend on results from earlier tests, length of the remaining period, nature and amount of changes, which are completed during the remaining period, evidence on effectiveness of control obtained through final auxiliary tests, etc. Business operations of large systems in contemporary conditions are unimaginable without contemporary computerized (accounting) information system (CIS). Management is responsible for creation, organization and work of such system, and auditors must be ready to perform quality control in such conditions. 
In order to be able to do it properly, it must entirely understand computerized accounting information system and all relevant control policies and procedures of the system in which this control is performed. Goals of auditing would ordinarily be the same. However, in the conditions of computerized accounting information system, attention must be directed at:

Transaction traces. Certain computerized accounting information systems are created in such a way that transaction trace can exist only in certain period, which controller should certainly know. If they assess that the relevant trace is not available in a given moment, they can demand from the personnel responsible for computerized accounting information system to perform its complete or partial reconstruction.

Separate functions. Many control procedures are most frequently unified in computerized accounting information system and taxation control should be able to separate them completely.

Possibility of errors and irregularities. There is a possibility of the existence of unauthorized access to certain data or even change to certain data without any visible trace. This relevant possibility represents a big limitation for auditing and due to it, it should dedicate most of its time to this area because it is very susceptible to errors, speculations, as well as criminal acts in the broadest sense.

Due to its good characteristics, contemporary computerized accounting systems have great advantages in relation to manual bookkeeping. Therefore, they are used in the largest number of companies today. However, due to these characteristics, there is a possibility for errors, fraud and even criminal acts to occur.

Specific technical controls have been developed in direct proportion to the development of CIS and there is such variety of them today that it is impossible to count them all. Thus, we will emphasize only a few of the possible approaches.

For example, tax control can decide on the so - called reversible method, which implies that firstly the most significant items in disclosed financial reports are identified and then they follow the transactions that influence each individual item from the financial report to the source document, i.e. backwards.

According to our opinion, other than this, the so-called real structural control is very effective. However, it is much harder to apply it since it demands the excellent knowledge of computers, but it usually provides good results in practice. This method implies that real data is implemented in computerized accounting information system after detailed information on the structure and functioning of computerized accounting information system is known and then comparison is performed with earlier verified results, thus grading reliability and accuracy of the company's computerized accounting information system. It is important to note that the combination of methods usually gives best results in proper understanding of financial reports.

Relevance is one of the most basic concepts in control in general, as well as in auditing. In this sense, information is relevant if leaving it out or showing it incorrectly could influence economic decisions of users based on financial report. After acquiring and evaluating evidence and implementing control procedures, an audit should ensure for reasonable belief that financial reports do not contain significant errors in regard to mechanical accuracy, existence, entirety, ownership, evaluation, classification and disclosure. Direct conduct of relevance in auditing is expressed as [8]:

- Preliminary assessment of relevance at the level of financial reports;

- Allocation of preliminary relevance to certain segments; and

- Assessment of probable mistake and its comparison to permissible error. 
Preliminary assessment of relevance at a financial report level represents the maximum deviation, which control believes that financial reports can contain that will not influence the other positions of financial reports. After calculating preliminary relevance according to certain methodology, its allocation to certain segments is performed. The following factors dominantly determine that allocation [9]:

- Relative participation of a given position;

- Possibility of an error; and

- Costs of a specific audit.

Work documentation of auditors must be complete and filled in detail, which practically means that it is possible to perform recapitulation of the entire procedure that auditors have conducted based on it. This is particularly significant when court disputes occur and there is a demand for compensation of damages. Quality and volume of documentation will greatly depend on the knowledge and experience of auditors, as well as their capabilities for analytical judgement.

\section{Identification of risks relevant to an audit}

When performing audits it is inevitable that mistakes occur and they carry a certain degree of risk.

One of the most important risks is sensibility of accounts and balance in financial reports on materially wrong reviews. Understanding this risk should be based on better knowledge of operations of certain business and its parts, as well as previously conducted analytical procedures and other control procedures. Considering that this risk is immanent in all business changes, it is necessary to perceive and quantify changes in the surroundings that provide the basis for its occurrence.

When assessing this risk, audits will primarily use professional judgement, especially in regard to [10]:

- Integrity of the management system;

- Experience and knowledge of the management system, as well as the influence of fluctuations in the management system;

- Unusual pressures on the management system (for example, in regard to conduct of certain activities);

- Nature of operations of a legal entity (for example, the expressed need for state subventions); and

- Other.

At the level of individual accounts and types of business events, certain accounts are susceptible to errors (most often those are sales revenue accounts, cost of amortization, cost of supplies, etc.), complexity of certain business changes, judgement degree when determining conditions, susceptibility of loss or illegal appropriation of assets, completion of unordinary and complex business changes and business events, which are not included in regular processing. [11]

For adequate risk assessment it is necessary to compare information on certain part of a company with relevant data on the other parts within a company or outside it. Auditors must know the accounting policy and business practice of a taxpayer very well, as 
well as functioning and basic characteristics of accounting information system and the level of adoption and implementation of accounting standards and principles.

It is impossible to conduct all control procedures, which should include policies and procedures of complete understanding of the entire business system of a taxpayer through an audit. When an audit completely grasps the taxpayer's system it must perform preliminary assessment of risk of all types and volume of business events.

Auditors should document the complete understanding of the taxpayer's business system in their working papers, as well as the assessment of relevant risks and their relation to total risk, which should all be documented in their working papers. Different methods and techniques, which have been presented, can be used for documentation. However, the most significant role is the experience of people, who perform the audit. [12]

In the future tax practice, there will often be a risk of failing to uncover the possibility of existence of wrong representation or a mistake that auditors will not be able to reveal by application of the current methods and analytical procedures. This risk most commonly occurs as a consequence of inefficient and insufficiently prepared procedures and to a smaller part because testing of transactions is almost always performed on the basis of samples. In order to reduce all relevant risks to an acceptable level, auditors should conduct all procedures of essential examination on all relevant positions, independently of assessed level of any individual risk.

\section{Conclusion}

Corporate income tax should be stable budget revenue with a tendency for continuous growth. Budget income based on this revenue should be secured through continuous control of taxpayers that pay this type of tax. The state tries to ease the conduct of the aforementioned by passing precisely defined norms through which information is presented and making sure that it is consistently applied. Conditions for implementation of these norms in practice are not easy at all, considering the fact that management of companies has the goal to achieve evasion of this type of tax. In this sense, it is necessary to devise and institutionalize an adequate auditing system.

In the paper we have defined this type of auditing as a process that is adopted by the state and systematically conducted, with the goal to provide security related to truthfulness of financial reports, in order to achieve the most important goals in the following domains: reliability of financial reporting, compliance with the existing laws and regulations (primarily tax), protection of assets from unlawful appropriation, use and alienation, as well as proper relation to the commitments that a company has to the society and the state. In order to achieve the set goals, the control needs to be devised and established in accordance with the principles applied in the developed countries. Adequate application of such principles should provide better methodology in performing the future tax audits. Bearing this in mind, we have presented certain theoretical and practical methods in the paper, which could be used when performing the future audits in the Republic of Serbia.

When we talk about new and still unaccepted methodology in our country, it is inevitable that certain limitations will occur in its implementation in our practice. We have identified those limitations in the paper, with the goal of their timely and better resolution. 
Every control carries certain risks, which primarily characterize tax audits. These risks have also been identified and analyzed.

On the basis of everything mentioned, we have come to the conclusion that it is necessary to modify the existing auditing system of the Republic of Serbia in accordance with experience of the developed countries and our specific needs. This also provides regular budgetary income and even redistribution of national income. The extent to which our country is ready to accept contemporary methodology of auditing will improve the level of quality of our economic and law system at the international level.

\section{Literature}

[1] Milojević I., Poreski bilans - instrument za utvrđivanje poreza na dobit, magistarska teza, Ekonomski fakultet, Beograd, 2007.

[2] Stiglic J., Ekonomija javnog sektora, Ekonomski fakultet, Beograd, 2004.

[3] Simijonović S., Interna kontrola i komponente interne kontrole, ODITOR, Centar za ekonomska i finansijska istraživanja, Beograd, 2(1), 2016, str. 30-35.

[4] Međunarodni standardi revizije, Savez računovođa i revizora Srbije, prevod, Beograd 2002.

[5] Dyckman D., Intrmediate Planing and Acounting, fifth edition, McGraw - Hill Iteranational Editon, 2001.

[6] Chenok P., AICPA Strategic Thrusts for the Future, Journal of Accountancy, January 1992.

[7] Vukša S., Milojević I., Analiza bilansa, Fakultet za menadžment BK, Beograd, 2007.

[8] Andžić S., Rajković M., Ćosić M., Nefinansijski aspekti poslovanja kao faktori razvoja preduzetništva, ODITOR, Centar za ekonomska i finansijska istraživanja, Beograd, 2(2), 2016, str. 7-17.

[9] Gill G., Modern Auditing and Assurance Services, 6th Edition, Monash University, 2002.

[10] Coosserat G., Modern Auditing, Nottingham Trent University, 1999.

[11] Raičević B., Javne finansije, Ekonomski fakultet, Beograd, 2005.

[12] Revisine, J., Financial Reporting and Analysis, second edition, Preteniceall, 2002.

[13] Kovačević M., llić J., Damnjanović R., Evolucija poreza na dohodak u Srbiji, ODITOR, Centar za ekonomska i finansijska istraživanja, Beograd, 3(1), 2017, str. 7-22. 